\title{
DINÂMICAS GEOMORFOLÓGICAS NA PRODUÇÃO DO ESPAÇO URBANO DA REGIÃO ADMINISTRATIVA DE GUARATIBA-RJ
}

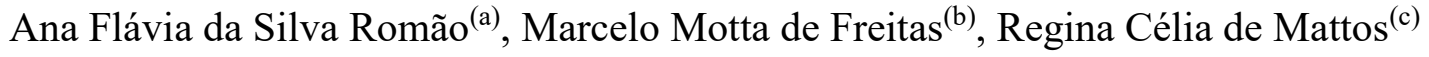 \\ (a) Graduanda em Geografia, PUC-Rio, anaflaviaromao@ hotmail.com \\ (b) Doutor em Geomorfologia, Professor do quadro principal no Depto de Geografia e Meio Ambiente, PUC-Rio, \\ marcelomotta@puc-rio.br \\ (c) Doutora em Geografia, Professora do quadro principal no Depto de Geografia e Meio Ambiente, PUC-Rio, \\ regina.mattos@globo.com
}

\section{Eixo: SISTEMAS GEOMORFOLÓGICOS: ESTRUTURAS DINÂMICAS E PROCESSOS}

\begin{abstract}
Resumo
Este trabalho busca um entendimento entre a produção do espaço urbano e a relação com as dinâmicas geomorfologicas da Região Administrativa de Guaratiba-RJ, analisando o adensamento urbano da região, atual eixo de expansão da cidade. Busca-se entender em qual medida o planejamento, investimentos e legislações da cidade viabilizam o risco a qualidade de vida na região da área de estudo, fazendo com que cenários de destres naturais comuns em outras áreas da cidade sejam novamente produzidos. Para esta análise serão elencados dados geomorfológicos, hidrológicos, geológicos e a pesquisa voltada para os campos da produção do espaço.
\end{abstract}

Palavras chave: Dinâmicas Geomorfológicas. Risco. Produção do Espaço

\section{Introdução}

Cada tipo de paisagem exige um planejamento específico, de forma a considerar as características naturais, tais como, relevo, geologia, solo, vegetação e dinâmicas hidrológicas na implantação das formas de ocupação urbana para minimizar os riscos à população. Para alcançar um bom planejamento espacial onde o conhecimento seja aplicado às realidades locais é fundamental o entendimento das formas de relevo, em diferentes escalas espaciais e temporais, além de compreender e explicar como elas se formam e evoluem. Cada área tem sua fragilidade definida pela combinação das características do meio físico e exige que se tenha atenção ao intervir. Diversos tipos de intervenções são feitas para viabilizar a ocupação urbana nos moldes em que são conduzidas atualmente, associadas a produção do espaço nos vários momentos históricos com as condições necessárias a produção e reprodução da vida.

Os relevos constituem os pisos sobre os quais se fixam as populações humanas e são desenvolvidas suas atividades, derivando daí valores econômicos e sociais que lhes são atribuídos. Em função de suas características os processos que sobre eles atuam, oferecem, para as populações tipos e níveis de 
benefícios ou riscos dos mais variados. Suas maiores ou menores estabilidades decorrem, ainda, de suas tendências evolutivas e das interferências que podem sofrer dos demais componentes ambientais.

Esta pesquisa busca associar a geomorfologia à produção do espaço em seus múltiplos níveis (econômico, político e social), considerando a análise das dinâmicas naturais como ferramenta para identificar riscos no uso do solo, como em Guaratiba, atual eixo de expansão da zona oeste da cidade do Rio de Janeiro. Deste modo buscaremos entender como o desenvolvimento histórico da cidade do Rio de Janeiro muitas vezes se deu em um desenho de ocupação em áreas consideradas irregulares por estarem contextualizadas em situações vulneráveis a fenômenos naturais dimensionados fisicamente (geológicos, geomorfológicos, hidrológicos). É comum que em tais áreas haja, em sua maioria, condições sociais abaixo dos padrões de vida considerados como de qualidade para a sociedade contemporânea que, associados às condições de relevo, tornam-se áreas de risco.

\section{Objetivos}

A preocupação com as características do sítio urbano sempre foi uma constante nos estudos geográficos sobre cidades. Neste sentido, buscamos identificar e caracterizar os compartimentos geomorfológicos da região administrativa de Guaratiba, bairro histórico do município do Rio de Janeiro que hoje vive intenso processo de ocupação. Focamos sobre as dinâmicas hidrológicas e erosivas das principais bacias de drenagem da RA Guaratiba, descrevendo e analisando as características morfológicas e suas associações com o substrato geológico. Justifica-se este trabalho pela identificação de riscos associados a processos erosivos e de inundação, baseado no entendimento do porque a produção do espaço se deu dessa forma e quais são os fatores determinantes na ocupação de Guaratiba. Ainda buscaremos entender quais as motivações para a existência de ações por parte do poder público que legitimam a ocupação dessas áreas. Quais os motivos que fortalecem os interesses econômicos em detrimento das dinâmicas naturais.

\section{Metodologia}

Os procedimentos metodológicos elencados para este trabalho são pesquisa bibliográfica voltada aos campos da geografia física teórica, da geomorfologia, da cartografia geomorfológica e de documentos técnicos (Plano Diretor e outros instrumentos de planejamento físico-territoriais urbanos).

Organizaremos a base de dados cartográficos e temáticos sobre o bairro. Neste sentido serão elencados os seguintes temas e fontes de pesquisa para dados secundários:

Geologia - levantamentos do CPRM/PRONAGEO

Geomorfologia - Levantamentos do CPRM e IPP/Prefeitura da cidade do Rio de Janeiro

Solos - Mapeamento da EMBRAPA-Solos 
Hidrografia - Levantamentos e dados da ANA e Rio Águas/IPP

Urbanização - Levantamentos do IPP e IBGE.

Para o levantamento de dados primários serão realizados levantamento de campo para a conferência e detalhamento dos dados secundários.

Por fim serão produzidos mapas que auxiliem a análise, serão eles, mapa hipsométrico, drenagens, concavidades (eixos concentradores), áreas alagáveis, cobertura vegetal, uso e ocupação, áreas protegidas e plano diretor. Estes mapas serão usados para cruzamento e comparação de informações para o alcance de uma visão integrada da área de estudo.

\section{Considerações Finais}

A RA Guaratiba tem um passado histórico voltado a prática agrícola e atualmente a moradia, sendo um importante eixo de expansão da cidade. A pesquisa encontra-se em caráter inicial, porém, já se percebe o processo de ocupação não respeitando as heranças dos ambientes preexistentes. Neste caso incluem-se as expansões recentes sobre os solos moles, de manguezais ou brejos, descritos assim pelo alto teor de argila e matéria orgânica, que garantem baixa sustentação para as construções sobre eles direcionadas. Neste sentido, o planejamento urbano integrado as dinâmicas naturais é premente para a evolução urbana do bairro, baseado em parâmetros de segurança e qualidade de vida.

\section{Bibliografia}

CARLOS, A. F. A. A condição espacial. São Paulo: Contexto, 2011.

CHRISTOFOLETTI, A. Aplicabilidade do conhecimento geomorfológico nos projetos de planejamento. In: GUERRA, A. J. T. \& CUNHA, S. B. Geomorfologia: Uma Atualização de Bases e Conceitos. Rio de Janeiro: Bertrand Brasil, 1995. p. 415-442.

HEILBRON, M., VALERIANI, C. D. M., VALLADARES, C. S., MACHADO, N. A orogênese brasiliana no segmento central da Faixa Ribeira, Brasil. Brazilian Journal of Geology, 25(4), 1995. p. 249-266.

MARQUES, J. S. Ciência Geomorfológica. In: Guerra e Cunha. et al. Geomorfologia: uma atualização de bases e conceitos. Rio de Janeiro: Bertrand Brasil, 2001. p. 23-50. 